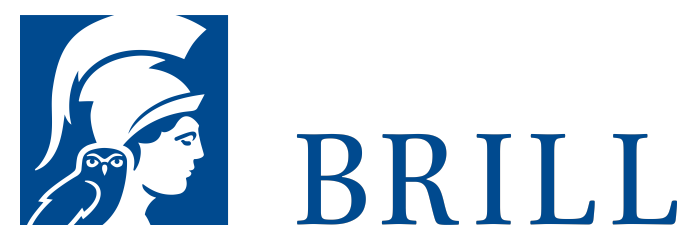

\title{
The Middle Voice in Ancient Greek
}

A Study of Polysemy

Author: Rutger Allan

Allan, Rutger The Middle Voice in Ancient Greek. A Study of Polysemy. 2003

The great variety of usage types of the middle voice in Ancient Greek has excited the interest of generations of classical scholars. A number of intriguing questions, however, still have been left unanswered. What is the exact relation between the various middle usage types? How can the semantic element common to all usage types be defined? What is the relation between the middle voice and the passive voice in the aorist and future stems? To provide an answer to these questions, this study takes a novel approach. Following recent developments in Cognitive Linguistics, the middle voice in Ancient Greek is analysed as a polysemous network category. This approach results in a unified description of the semantics of the middle voice which also accounts for diachronical developments. ASCP 11 (2003), 286 p. Cloth - 79.0o EURO, ISBN: 9050633684

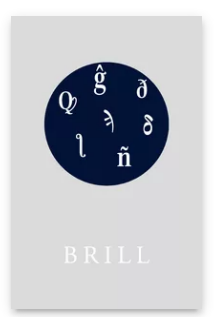

Pages: $286 \mathrm{pp}$.

Language:

English

Subjects: Greek \& Latin

Literature, Classical Studies

Publisher: Brill

Series:

Amsterdam

Studies in

Classical

Philology,

Volume: 11

E-Book (PDF)

Released online: 16 Sep 2019

ISBN: 978-9004-409o6-4 List price

USD \$134.00

Hardback

Publication date:

o1 Jan 2003

ISBN: 978-90-

50-63368-о

List price

USD \$134.00 
Biographical Note

Rutger J. Allan (Ph.D 2002) is Lecturer in Greek language and literature at the Free University Amsterdam.

For more information see brill.com

\begin{abstract}
Order information: Order online at brill.com
+44330 333 0049 | customerservices@brill.com

Submission information: brill.com/authors
\end{abstract}

Titles published by Brill | Fink, Brill | mentis or Brill | Schöningh: +49(o)71 5413279216 | brill@brocom.de 